\title{
Ginger (Zingiber officinale) powder from low temperature drying technique
}

\author{
A. K. Sarker ${ }^{1}$, M. Rashid ${ }^{2 *}$, D. C. Roy ${ }^{1}$, M. Musarrat ${ }^{2}$ and U. H. Bithi ${ }^{2}$ \\ ${ }^{1}$ Biomedical and Toxicological Research Institute (BTRI), Bangladesh Council of Scientific \& Industrial Research (BCSIR), \\ Dhaka-1205, Bangladesh \\ ${ }^{2}$ Institute of Food Science and Technology (IFST), Bangladesh Council of Scientific \& Industrial Research (BCSIR), \\ Dhaka-1205, Bangladesh
}

Received: 15 December 2020

Revised: 07 March 2021

Accepted: 31 March 2021

DOI: https://doi.org/10.3329/bjsir.v56i1.54320

\begin{abstract}
Ginger (Zingiber officinale) powder was prepared using different low temperature drying techniques and their nutritional, phytochemicals, functional and sensory quality were investigated. Moisture content was significantly $(\mathrm{p}<0.05)$ higher $(7.16 \pm 0.04 \%)$ in shade dried powder and lowest in oven dried powder. Protein, fat and fiber contents varied with drying techniques ranging from $6.08 \pm 0.05$ to $6.68 \pm 0.07 \%, 1.08 \pm 0.16$ to $1.39 \pm 0.25 \%$ and $3.86 \pm 0.13$ to $5.11 \pm 0.06 \%$ respectively. Highest alkaloid content was found in mechanical dried powder $(4.44 \pm 0.04 \%)$, while highest flavonoid content was found in oven dried ginger powder $(4.67 \pm 0.07 \%)$ and maximum saponin content was recorded in shade dried powder $(2.67 \pm 0.10 \%)$. Highest ascorbic acid content $(3.53 \pm 0.08 \mathrm{mg} / 100 \mathrm{~g})$ was found in shade dried powder and lowest was recorded in oven dried ginger powder $(3.53 \pm 0.08 \mathrm{mg} / 100 \mathrm{~g})$. Sun drying technique exhibited better nutritional and sensory quality. The sensory score demonstrated acceptance of all dried ginger powder was in the range of liked very much to liked moderately by the panelist. Low temperature drying techniques have positive significance on retaining phytochemicals and sensory quality of processed ginger.
\end{abstract}

Keywords: Drying techniques; Nutritional composition; Functional property; Mineral content; Sensory quality

\section{Introduction}

Ginger (Zingiber officinale) is a herbaceous perennial flowering plant belongs to the Zingiberaceae family. Traditionally it is known as oldest spice and used as folk medicine. This plant is used around the whole world in food as a spice in dried and fresh conditions for enhancing the flavor, make spicy and pungency taste to the meal (Jayashree and Visvanathan, 2011). It is a good source of minerals and vitamins (i.e. $\beta$-carotene, ascorbic acid). This plant used as food masala (i.e. pickles, cookies, marmalade) in confectionery, seasoning and flavoring material in diet, bakery products and alcoholic and non-alcoholic beverage (Plotto, 2002). Fresh ginger is a perishable spice causes of improper postharvest management and changes in micro constituent for chemical reaction during storage time. Postharvest management of ginger is not well developed (Pruthi, 1993). But, it is important to explore alternative techniques for processing fresh ginger industrially. Drying is the alternative techniques for producing ginger powder and allows them to use in off-season. Dried powder is a substitute product of fresh ginger and stored for long time holding its

\footnotetext{
*Corresponding author e-mail: mamunrashid810@gmail.com
} 
freshness. It takes small space and lighter in weight rather than raw ginger. For longer shelf life, the dried powder can be an effective solution for processors to make it as a commercial product. It can also be considered as processed product for ready to use in restaurants and homes (Ahmed and Shivhare, 2001). Moreover, dried ginger powder is less prone to microbial contamination (Prasad et al., 2006). There are different drying techniques including sun drying, microwave drying, vacuum drying, freeze drying etc. (Jayashree et al., 2014). The drying techniques can affect the phytochemicals, flavor and color of processed powder. For this, it is an important factor to maintain optimal temperature and rational heat dosage (Figiel, 2010). For producing ginger powder, low temperature drying techniques can be effective for retaining color, flavor, phytochemicals and nutritional contents. Therefore, the objective of this study was to evaluate the nutritional, functional and sensorial quality of low temperature dried ginger powder.

\section{Ginger powder preparation}

Collected ginger rhizomes were washed with running tap water. For improving the shelf life, gingers were cut into 2-5 $\mathrm{mm}$ slices and dehydrated using the following four different drying techniques.

i. Sun drying (SD) - sliced ginger were dehydrated in hot sunlight.

ii. Oven drying (OD) - sliced ginger were dehydrated at (50 $\pm 5)^{\circ} \mathrm{C}$ for $6-8$ hours.

iii. Mechanical drying (MD)- sliced ginger were dehydrated in hot air mechanical dryer.

iv. Shade drying (SHD) - sliced ginger was dehydrated in shade maintaining room temperature.

Dehydrated ginger slices were ground using a grinder for making fine powder as shown in Fig. 1. Prepared ginger powder was stored at $4^{\circ} \mathrm{C}$ in low dense airtight polyethylene

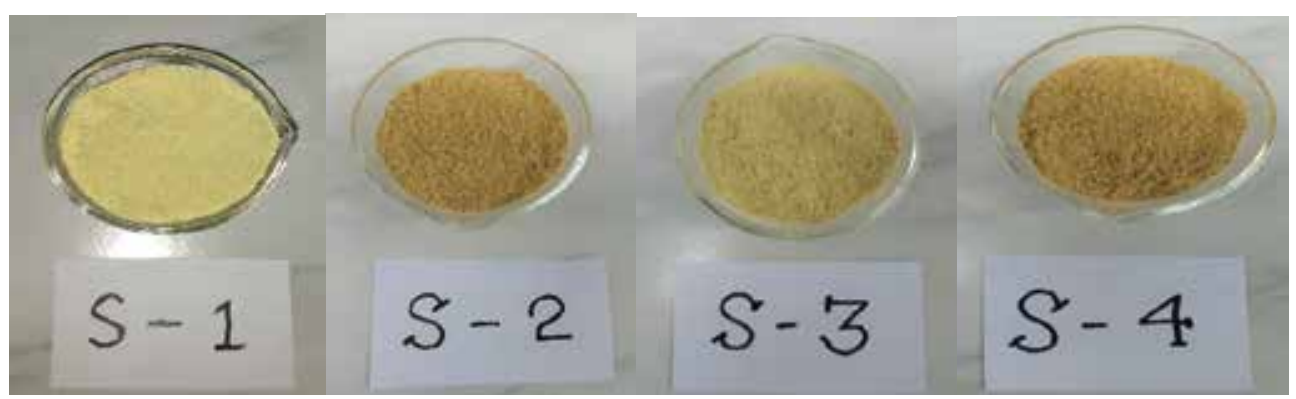

Where: S-1=Oven dry; S-2=Sun dry; S-3= Mechanical dry; S-4=Shade dry

Fig. 1. Prepared ginger powder at four different drying techniques

\section{Materials and methods}

This research was conducted at the Laboratory of Plant Protein Research Section of Institute of Food Science and Technology, Bangladesh Council of Scientific and Industrial Research (BCSIR), Bangladesh.

\section{Raw materials collection}

Fresh and matured ginger rhizome was collected from local market near BCSIR for study. All chemicals and reagent used in this study were collected from Alfaaesar, UK. bag for further analysis. Chemically color cleaned ginger were blanching and soaking into boiling water for $10-15 \mathrm{sec}$. Then immersed in $0.2 \%$ potassium metabisulphite (KMS) solution for $5 \mathrm{~min}$ at room temperature (Singh et al., 1997).

\section{Methods of analysis}

All experiment parameters were conducted at ambient temperature and repeated three times. Nutritional composition (i.e. moisture, ash, crude fat, protein and crude fiber) of dried ginger powder were estimated following AOAC methods (AOAC, 2005). Digestible carbohydrate content was estimated simply by difference (Eneche, 1999). Sodium and potassium contents were estimated following the 
flame photometric method (Mutalik et al., 2011). Calcium, iron and zinc contents were estimated following the Atomic Absorption Spectrophotometric (AAS) method (AOAC, 2005). Alkaloid content was estimated following the method described by Harborne (1998). Flavonoid content was estimated following the method reported by Bohm and Koupai (1974). Saponin content was determined following this method described by Ejikeme et al. (2014). Ascorbic acid content was estimated following 2, 6-dichlorophenol indophenol titration procedure described by Rao and Deshpande (2006). pH was estimated at room temperature with sample dilution by a digital $\mathrm{pH}$ meter. Total titrable acidity was estimated in terms of acetic acid (\%) following method described by Ranganna (1986). Bulk density, foaming capacity, swelling power capacity and solubility index were estimated following method reported by Adegunwa et al. (2017). Water absorption capacity was determined following method described by Sosulski (1962).

\section{Sensory evaluation}

Sensory evaluation of dehydrated ginger powder was conducted by a 10 panelist of consumer test panel in the view of 9 points hedonic scale (IS: 6273,1971$)$. Sensory attributes were taste, flavor, color, and overall acceptability.

\section{Statistical analysis}

Statistical data were analyzed using SPSS (Statistical Package for Social Sciences) software, version 22, SPSS Inc. Chicago, Illinois, USA. Data values were expressed as a percentage and mean \pm SD. One-way ANOVA (analysis of variance) along with Bonferroni post hoc test was used to analyze the significance/non-significance of the mean values between different groups. The findings were considered as statistically significant, if $\mathrm{p}<0.05$.

\section{Results and discussion}

The proximate composition result of ginger powder using different drying methods (viz. SD, OD, MD, and SHD) were presented in Table I. The moisture content is the major concern for shelf life of processed ginger, because higher moisture content decreases the shelf life of ginger powder. In this study, highest moisture content was evident in SHD ginger powder $(7.16 \pm 0.04 \%)$ and was significantly $(p<0.05)$ different from other dried ginger powder. On the other hand, OD ginger powder showed lowest moisture content $(4.02 \pm 0.08 \%)$, whereas, MD and SD dried ginger powder showed lower or moderate moisture content $(4.27 \pm$ $0.14 \%)$ and $(5.17 \pm 0.15 \%)$, respectively. The oven drying technique was found more effective in decreasing moisture content in ginger powder than other drying techniques used in this study. Similar experimental findings were observed in other studies (Bankole et al., 2005).

Ash content was determined in this study as it indicates presence of minerals in food stuffs. Highest amount ash content $(4.04 \pm 0.10 \%)$ was found in MD ginger powder and lowest in SHD ginger powder $(3.31 \pm 0.12 \%)$. Ash content of SD powder $(3.71 \pm 0.09 \%)$ was slightly higher than OD $(3.52 \pm 0.08 \%)$ powder. Similar results with SD and SHD

Table I. Proximate composition of prepared ginger powder using different drying techniques

\begin{tabular}{lllll}
\hline Parameters & Sun dry & Oven dry & Mechanical dry & Shade dry \\
\hline Moisture(\%) & $5.17 \pm 0.15$ & $4.02 \pm 0.08^{*}$ & $4.27 \pm 0.14^{*}$ & $7.16 \pm 0.04^{*}$ \\
Ash(\%) & $3.71 \pm 0.09$ & $3.52 \pm 0.08$ & $4.04 \pm 0.10^{*}$ & $3.31 \pm 0.12^{*}$ \\
Acid insoluble ash(\%) & $0.34 \pm 0.11$ & $0.28 \pm 0.14$ & $0.42 \pm 0.09$ & $0.30 \pm 0.13$ \\
Fat(\%) & $1.22 \pm 0.21$ & $1.08 \pm 0.16$ & $1.18 \pm 0.21$ & $1.39 \pm 0.25$ \\
Organic matter(\%) & $91.24 \pm 0.14$ & $92.44 \pm 0.18^{*}$ & $91.69 \pm 0.16$ & $89.51 \pm 0.18^{*}$ \\
Protein(\%) & $6.45 \pm 0.09$ & $6.68 \pm 0.07^{*}$ & $6.08 \pm 0.05^{*}$ & $6.32 \pm 0.03$ \\
Crude fiber(\%) & $4.67 \pm 0.10$ & $3.86 \pm 0.13^{*}$ & $5.11 \pm 0.06$ & $4.80 \pm 0.12$ \\
Carbohydrate(\%) & $79.22 \pm 0.12$ & $80.78 \pm 0.17^{*}$ & $79.34 \pm 0.11$ & $77.21 \pm 0.22^{*}$ \\
TTA(\%) & $0.48 \pm 0.05$ & $0.39 \pm 0.08$ & $0.36 \pm 0.09$ & $0.51 \pm 0.0$ \\
pH & $4.96 \pm 0.07$ & $4.96 \pm 0.05$ & $4.83 \pm 0.08$ & $4.98 \pm 0.11$ \\
\hline
\end{tabular}

Values are means of triplicates \pm SD. Values with *asterisk indicates in a row significantly different from sun dried powder, where $\mathrm{p}<0.05$ 
ginger powder were reported by Sangwan et al. (2014). On the other hand, acid insoluble ash content was also measured since it represents the digestibility of food (El-Ghorab et al., 2010) Variation of acid insoluble ash content was observed between $\mathrm{OD}(0.28 \pm 0.14 \%)$ and $\mathrm{MD}(0.42 \pm 0.09 \%)$ ginger powder. Little higher amount of acid insoluble ash was observed in SD ginger powder $(0.34 \pm 0.11 \%)$ and SHD ginger powder $(0.30 \pm 0.13 \%)$.

Protein content was determined as it is related to the water absorption capacity, texture and volume of the dried ginger samples. Highest protein content was observed in OD ginger powder $(6.68 \pm 0.07 \%)$ and lowest amount was seen in MD ginger powder $(6.08 \pm 0.05 \%)$. No significant difference $(\mathrm{p}<0.05)$ was noticed between SD ginger powder $(6.45 \pm 0.09 \%)$ and SHD ginger powder $(6.32 \pm 0.03 \%)$. Similar findings related to protein content have been reported in other studies (Sangwan et al., 2014).

Fat content was measured as it is responsible for holding flavor of the ginger powder and low fat content closely connected to shelf life (Rahman et al., 2013). The fat content of SD, OD, MD and SHD ginger powder were found to be $(1.22 \pm 0.21 \%), \quad(1.08 \pm 0.16 \%), \quad(1.18 \pm 0.21 \%) \quad$ and $(1.39 \pm 0.25 \%)$, respectively. No significant difference $\mathrm{p}<0.05$ was observed between the drying techniques used in this study. This finding was corresponded with OD and SD powder reported by Ajayi et al. (2017).

Crude fiber content was determined as it indicates the presence of organic content and the lowest crude fiber was found in OD ginger powder $(3.86 \pm 0.13 \%)$, which was significantly different than other drying techniques. Highest crude fiber content was estimated in MD ginger powder $(5.11 \pm 0.06 \%)$ and slightly lower crude fiber content was estimated in SHD ginger powder $(4.80 \pm 0.12 \%)$ and SD ginger powder (4.67 \pm 0 . 10\%). A good amount of fiber content benefits in easing indigestion problem (Ozgoli et al., 2009).

The organic matter ranged between $(89.51 \pm 0.18 \%)$ in SHD to $(92.44 \pm 0.18 \%)$ OD powder.MD powder organic matter was little bit higher than SD powder. Carbohydrate content of OD $(80.78 \pm 0.17 \%)$ was significantly highest and lowest amount in $(77.21 \pm 0.22 \%)$ in SHD powder. No significant difference was found in SD and MD powder. The result indicates that dried ginger powder contains a good amount of carbohydrate and can be graded as a carbohydrate-rich ginger powder, which is good source of energy.
The $\mathrm{pH}$ value for the SD, OD, MD and SHD ginger powder were $4.96 \pm 0.07,4.96 \pm 0.05,4.83 \pm 0.08$, and $4.98 \pm 0.11$, respectively. The $\mathrm{pH}$ ranges $3.5-5.5$ indicate the protein solubility in flour. In low acid and high alkaline $\mathrm{pH}$ value causes more charges and creating repulsion among the molecules. Protein-protein interaction increases the electrostatic force and water molecules interacts with protein molecules. This is a favorable condition for protein molecules to approach each other and get aggregate. At $\mathrm{pH}$ value above 6.5 and below 3.5 protein molecules have net positive or negative charges; similarly, water molecule interacts with protein charges. Net charges and charge repulsion contribute to greater protein solubility (Mann et al., 1996). Lower $\mathrm{pH}$ value indicates more stable against microbial contamination.

Titrable acidity was maximum $(0.51 \pm 0.06 \%)$ in SHD and minimum $(0.36 \pm 0.09 \%)$ in MD. Non significant difference $(p<0.05)$ was observed in titrable acidity of dried powder. Similar results were also observed by Choi et al. (2012). The mineral contents and phytochemicals of produced ginger powder are presented in Table II. The ginger powder would be good source of essential mineral.

Human body requires different types of minerals because each minerals has a different set of functions and this requirement depends on age, sex and physiological state. $\mathrm{Na}$ is responsible for regulating body water and electrolyte balance and also required for absorption of certain nutrients from the gut. In this study, $\mathrm{Na}$ content was highest in OD $(6.58 \pm 0.03 \mathrm{mg} / 100 \mathrm{~g})$ ginger powder and lowest in SD $(4.19 \pm 0.02 \mathrm{mg} / 100 \mathrm{~g})$ ginger powder. $\mathrm{Na}$ content of $\mathrm{MD}$ $(6.22 \pm 0.04 \mathrm{mg} / 100 \mathrm{~g})$ ginger powder was higher than SHD $(4.27 \pm 0.02 \mathrm{mg} / 100 \mathrm{~g})$ ginger powder. Ca is the most abundant essential mineral content in human body and also essential for intracellular signaling to enable the integration and regulation of metabolic process via nerve system. Ca content was estimated for its biological importance and highest amount was in MD (308.64 $\pm 0.09 \mathrm{mg} / 100 \mathrm{~g})$ ginger powder and lowest amount in OD $(139.85 \pm 0.08 \mathrm{mg} / 100 \mathrm{~g})$ ginger powder. $\mathrm{Ca}$ content for SD and SHD ginger powder were $(251.24 \pm 0.07 \mathrm{mg} / 100 \mathrm{~g})$ and $(188.62 \pm 0.07 \mathrm{mg} / 100 \mathrm{~g})$, respectively. $\mathrm{K}$ is the one of the essential mineral and has the capacity of regulating electrolyte balance and also normalize the nerve cell functioning in human body. In this study, highest amount $\mathrm{K}$ content was seen in MD $(26.35 \pm 0.07$ $\mathrm{mg} / 100 \mathrm{~g})$ powder and lowest amount in SHD (20.45 \pm 0.06 $\mathrm{mg} / 100 \mathrm{~g}$ ) powder. Similar findings related to K content have been reported in other studies (Famurewa et al., 2011). Fe is essential for formation hemoglobin in red blood cells and also an essential component in many enzymatic reactions in human body. This mineral boost up the human immune 
Table II. Mineral contents and phytochemicals of prepared ginger powder

\begin{tabular}{lllll}
\hline Ginger Powder & Sun Dry & Oven dry & Mechanical Dry & Shade Dry \\
\hline $\mathrm{Na}(\mathrm{mg} / 100 \mathrm{~g})$ & $4.19 \pm 0.02$ & $6.58 \pm 0.03^{*}$ & $6.22 \pm 0.04^{*}$ & $4.27 \pm 0.02$ \\
$\mathrm{~K}(\mathrm{mg} / 100 \mathrm{~g})$ & $25.25 \pm 0.04$ & $21.65 \pm 0.05^{*}$ & $26.35 \pm 0.07^{*}$ & $20.45 \pm 0.06^{*}$ \\
$\mathrm{Fe}(\mathrm{mg} / 100 \mathrm{~g})$ & $4.65 \pm 0.04$ & $4.23 \pm 0.05^{*}$ & $2.59 \pm 0.07^{*}$ & $3.95 \pm 0.06^{*}$ \\
$\mathrm{Ca}(\mathrm{mg} / 100 \mathrm{~g})$ & $251.24 \pm 0.07$ & $139.85 \pm 0.08^{*}$ & $308.64 \pm 0.09^{*}$ & $188.62 \pm 0.07^{*}$ \\
$\mathrm{Zn}(\mathrm{mg} / 100 \mathrm{~g})$ & $11.45 \pm 0.03$ & $11.20 \pm 0.04^{*}$ & $9.13 \pm 0.06^{*}$ & $9.01 \pm 0.08^{*}$ \\
Alkaloid(\%) & $3.25 \pm 0.09$ & $4.10 \pm 0.05^{*}$ & $4.44 \pm 0.04^{*}$ & $3.15 \pm 0.03$ \\
Flavonoid(\%) & $3.52 \pm 0.08$ & $4.67 \pm 0.07^{*}$ & $3.72 \pm 0.13$ & $3.13 \pm 0.07^{*}$ \\
Saponin(\%) & $1.68 \pm 0.09$ & $1.78 \pm 0.07$ & $2.36 \pm 0.07^{*}$ & $2.67 \pm 0.10^{*}$ \\
Ascorbic acid (mg/100g) & $2.84 \pm 0.07$ & $2.48 \pm 0.09^{*}$ & $3.18 \pm 0.05^{*}$ & $3.53 \pm 0.08^{*}$ \\
\hline
\end{tabular}

Values are means of triplicates \pm SD. Values with *asterisk indicates in a row significantly different from sun dried powder, where $\mathrm{p}<0.05$.

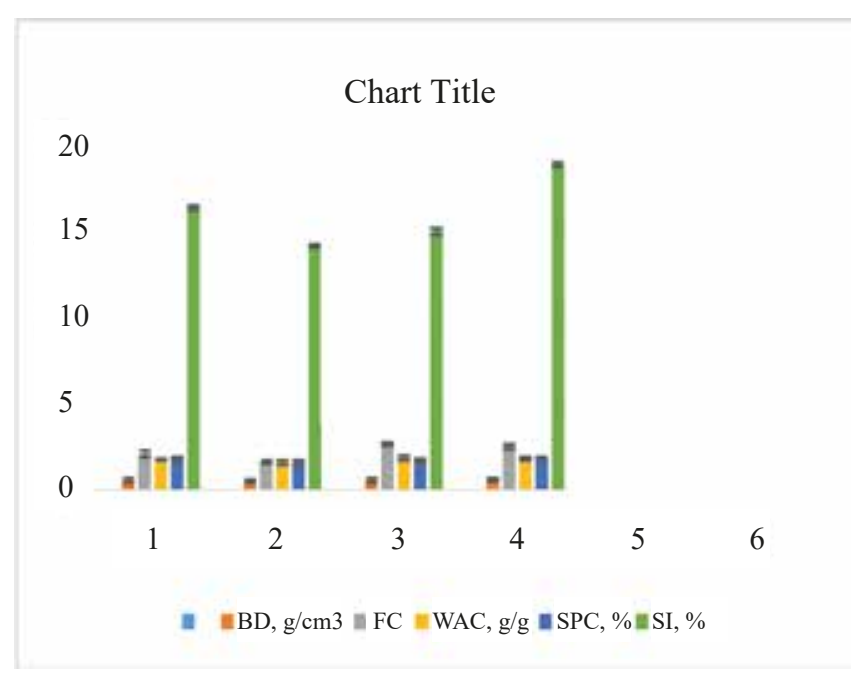

Fig. 2. Functional property of ginger powder

system. Highest amount of Fe content was seen in SD ginger $(4.65 \pm 0.04 \mathrm{mg} / 100 \mathrm{~g})$ and lowest amount in MD $(2.59 \pm 0.07$ $\mathrm{mg} / 100 \mathrm{~g}$ ) ginger powder. The main function of $\mathrm{Zn}$ in human metabolism as a cofactor of numerous enzymes. It is directly or indirectly involved in the major metabolic pathways concerned with protein, lipid, carbohydrate and energy metabolism and is also essential for cell division, tissue repair and normalize the reproductive system. Highest amount of $\mathrm{Zn}$ content was estimated in (11.45 \pm 0.03 $\mathrm{mg} / 100 \mathrm{~g}$ ) in SD ginger powder and lowest amount in $(9.01 \pm 0.08 \mathrm{mg} / 100 \mathrm{~g}) \quad$ SHD ginger powder. However, minerals are inorganic substances required for body in small amounts for variety of body metabolic functions.
Alkaloids are a class of basic naturally organic compounds and have anti-inflammatory analgesic, local anesthetic and pain relief properties. Alkaloid concentration becomes low at the maturation stage and this concentration also depends on the season. In this study, highest amount of alkaloid was seen in MD (4.44 $\pm 0.04 \%)$ ginger powder and was significantly different $(p<0.05)$. Lowest amount of alkaloid was seen in SHD $(3.15 \pm 0.03 \%)$ ginger powder. Flavonoids are one of the abundant phytochemicals in plant, for which they perform several function such as UV-filtration, cell-cycle inhibition and chemical messengers. Highest amount of flavonoid was seen in OD $(4.67 \pm 0.07 \%)$ ginger powder and was significantly different $(\mathrm{p}<0.05)$. In this study, lowest amount of flavonoid was seen in SHD (3.13 $\pm 0.07 \%)$ ginger powder. Drying techniques are a potential factor for flavonoid content results. High temperatures denature the cellular constituents and help to release flavonoid concentration. But, a short aspect of time within the drying techniques prepares it useful about flavonoid preservation (An et al., 2016). Saponins are one of the most numerous and diverse groups of plant natural products and having the properties of improving immune function and works as antioxidants and scavenge oxidative stress. Saponin concentration depends on $\mathrm{pH}$ and temperature. Due to the increase of $\mathrm{pH}$ and temperature, the saponin concentration become decreasing. Highest amount of saponin content was seen in SHD $(2.67 \pm 0.10 \%)$ ginger powder and was significantly different $(p<0.05)$ in this study. Lowest amount of saponin was seen in SD $(1.68 \pm 0.09 \%)$ ginger powder. In this study, ascorbic acid content ranged from $2.48 \pm 0.09$ $\mathrm{mg} / 100 \mathrm{~g}$ in OD to $3.53 \pm 0.08 \mathrm{mg} / 100 \mathrm{~g}$ in SHD ginger powder. Water-soluble ascorbic acid is one of the crucial antioxidant found in nature. The concentration of ascorbic 
acid depends on temperature, maturation stage and storage period (Koomson et al., 2018).

\section{Functional property}

From the Fig. 2. of functional property, the bulk density of all dried ginger powder was in lower range (below 1.0 $\left.\mathrm{g} / \mathrm{cm}^{3}\right)$. Lower bulk density results reasons for homogeneousness of particle and reducing the inter-particles voids the surrounding surface area become decreased. It influenced the structural arrangement of carbohydrate and other polymer in flour. From the graph all dried ginger powder showed low foaming capacity (below 3.0). It is related to surface tension; protein molecules absorb water for which surface tension decreased. Low foaming capacity indicates presence of flexible protein in flour (Shathe et al., 1982). Water absorption capacity indicates holding water for consistency of flour. It is related to moisture, polysaccharide, starch and protein content. All dried ginger powders have lower water absorption capacity (below $2 \mathrm{~g} / \mathrm{g}$ ) for which it contains less protein, polysaccharide and starch. Swelling power capacity has a correlation with presence of amylose content (Singh, 2010). Ginger powder showed lower swelling power capacity (below $2.0 \%$ ). Lower swelling power indicates the presence of lower amount amylose content and hydrophilic groups in flour (Kaur et al., 2007). All dried powder showed solubility index below $20 \%$. Solubility index indicates presence of soluble molecules in flour. Functional property result indicates dried ginger powder have a good capacity of a finished product ingredient.

\section{Sensory quality}

Sensory quality of dehydrated ginger powder is represented in Fig. 3. SD ginger powder scored maximum in all attributes including color, aroma, texture, appearance, and overall acceptability and a lower score for OD powder. In the point of color and aroma attributes SD powder scored high $7.80 \pm 0.10$ and $7.66 \pm 0.15$ respectively. In point of texture attribute, SD powder scored high (7.50 \pm 0.20$)$. Different drying techniques robustly influenced the appearance of dried ginger powder. Drying techniques are closely related to the appearance attribute which created a bridge bond between color, aroma, texture, appearance, and acceptance of ginger powder(Sangwan et al., 2014). However, mean scores for sensory attributes indicated that prepared ginger powder was in the range of liked very much to like moderately.

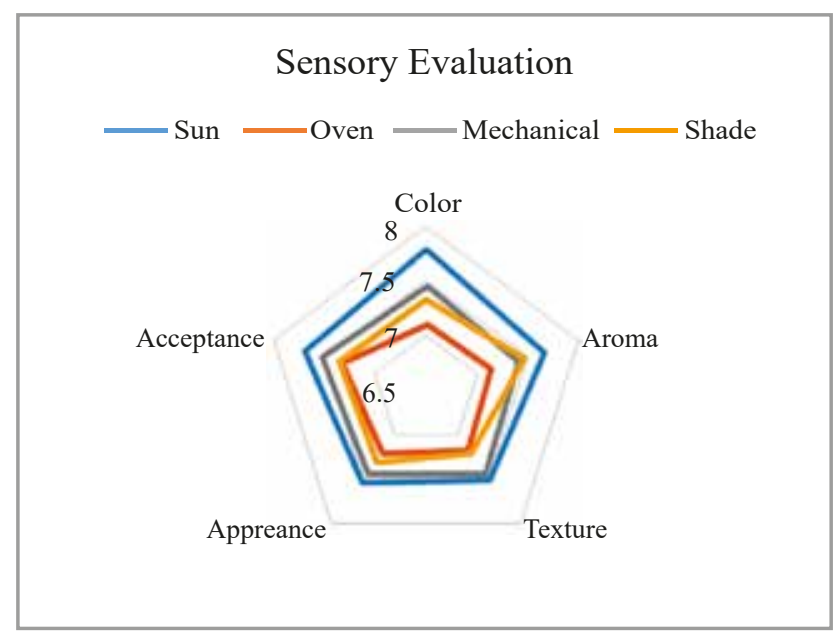

Fig. 3. Sensory quality of prepared ginger powder

\section{Conclusion}

The study results demonstrated that sun drying technique exhibited better nutritional and sensory quality as compared to other drying techniques used in this study. Although, the moisture content of oven dried ginger powder was the lowest but sundried powder showed better sensory quality. Sensory score demonstrated that acceptance of all dried ginger powder was in the range of liked very much to liked moderately by the panelist. Low temperature drying techniques showed a positive effect on retaining phytochemicals and good sensory attributes for producing ginger powder. Low temperature drying techniques can be an effective way for post-harvest management of raw ginger for farmers and small-scale processors. Processed ginger can make contribution to the national economy if formulated commercially.

\section{Acknowledgement}

This research work was conducted under the R\&D work "Development of Nutraceutical Product for Diarrheal patient" Reference no. 39.02.0000.011.14.111.2019/224 project of IFST, BCSIR, Bangladesh. Authors are thankful to the Directors of Institute of Food Science and Technology (IFST) and Biomedical and Toxicology Research Institute (BTRI), Bangladesh Council of Scientific and Industrial Research (BCSIR), Dhaka, Bangladesh for supporting this research work. 


\section{References}

Adegunwa MO, Adelekan EO and Adebowale AA (2017), Evaluation of nutritional and functional properties of plantain (Musa paradisiaca L.) and tigernut (Cyperus esculentus L.) flour blends for food formulations, Cogent Chem 3: DOI: org/10.1080/ 23312009.2017.1383707

Ahmed J and Shivhare US (2001), Thermal kinetics of color change, rheology, and storage characteristics of garlic puree/paste, J Food Sci 66: 754-757. DOI: org/ 10.1111/j.1365-2621.2001.tb04633.x

Ajayi OA, Ola OO and Akinwunmi OO (2017), Effect of drying method on nutritional composition, sensory and antimicrobial properties of Ginger (Zinginber officinale), Int Food Res J. 24: 614-620

An K, Zhao D and Wang Z (2016), Comparison of different drying methods on Chinese ginger (Zingiber officinale Roscoe): Changes in volatiles, chemical profile, antioxidant properties, and microstructure, Food Chem 197: 1292-1300. DOI: org/10.1016/ j.foodchem. 2015.11 .033

AOAC (2005), Official Methods of Analysis of AOAC International, $18^{\text {th }}$ Ed., AOAC International, Gaithersburg, Md.

Bankole SA, Osho A, Joda AO and Enikuomehin OA (2005), Effect of drying method on the quality and storability of "egusi" melon seeds (Colocynthis citrullus L.), African J Biotechno 4: 799-803

Boham BA and Kocipai AC (1974), Flavonoids and Condensed Tannins from Leaves of Hawaiian Vaccinium vaticulatum and V. calycinium, Pacific Sci 48: 458-463.

Choi EJ, Lee KA, Kim BS and Ku KH (2012), Effect of pre-treatment and storage conditions on the quality characteristics of ginger paste, Prev Nutr Food Sci. 17: 46-52. DOI: org/10.3746/pnf.2012.17.1.046

Eneche EH (1999), Biscuit-making potential of millet/pigeonpea flour blends, Plant Foods for Hum Nutr. 54: 21-27. pea flour blends, Plant Foods for Hum Nutr. 54: 21-27.

Ejikeme CM, Ezeonu CS and Eboatu AN (2014), Determination of physical and phytochemical constituents of some tropical timbers indigenous to niger delta area of nigeria, European Scientific Journal 10(18): 247-270.

El-Ghorab AH, Nauman M and Anjum FM (2010), A Comparative study on chemical composition and antioxidant activity of ginger (Zingiber officinale) and cumin (Cuminum cyminum), J Agric Food Chem 58: 8231-8237. DOI: org/10.1021/jf101202x

Famurewa AV, Emuekele PO and Jaiyeoba KF (2011), Effect of drying and size reduction on the chemical and volatile oil contents of ginger (Zingiber officinale), $J$ Med Plants Res 5: 2941-2944

Figiel A (2010), Drying kinetics and quality of beetroots dehydrated by combination of convective and vacuum-microwave methods, Journal of Food Engineering 98(4): 461-470

Harborne AJ (1998), Phytochemical Methods: A Guide to Modern Techniques of Plant Analysis, $3^{\text {rd }}$ Ed. Springer, Netherlands.

Jayashree E and Visvanathan R (2011), Physical and biochemical parameters of fresh and dry ginger (Zingiber officinale Roscoe). J Spices Aromat Crop 20: $14-21$

Jayashree E, Visvanathan R and John Zachariah T (2014), Quality of dry ginger (Zingiber officinale) by different drying methods, J Food Sci Technol 51: 3190-3198. DOI: org/10.1007/s13197-012-0823-8

Kaur A, Singh N, Ezekiel R and Guraya H (2007), Physicochemical, thermal and pastingproperties of starches separated from different potato cultivars grown at different location, Food Chemistry 101: 643-651

Koomson DA, Kwakye BD and Darkwah WK (2018), Phytochemical constituents, total saponins, alkaloids, flavonoids and vitamin c contents of ethanol extracts of five solanum torvum fruits, Pharmacogn $J$ 10: 946-950. DOI: org/10.5530/pj.2018.5.160

Mutalik VK, Baragi JG and Mekali SB (2011), Determination of estimation of potassium ion in dry fruits by flame photometry and their proximate analysis, J Chem Pharm Res 3: 1097-1102.

Mann B and Malik RC (1996), Studies on some functional characteristics of whey protein-polysaccharide 
complex, Journal of Food Science and Technology 33(3): 202-206.

Ozgoli G, Goli M and Simbar M (2009), Effects of ginger capsules on pregnancy, nausea, and vomiting, J Altern Complement Med 15: 243-246. DOI: org/10.1089/ acm.2008.0406

Plotto A (2002), Ginger: post-production management for improved market access

Prasad J, Vijay VK, Tiwari GN and Sorayan VPS (2006), Study on performance evaluation of hybrid drier for turmeric (Curcuma longa L.) drying at village scale, $J$ Food Eng. 75:497-502. DOI: org/10.1016/ j.jfoodeng. 2005.04.061

Pruthi JS (1993), Major spices of India: crop management and post-harvest technology, Indian Council of Agricultural Research.

Rahman MJ, Talukder MAI and Rani L (2013), The effect of processing techniques on the shelf life, nutritional and sensory quality of ginger (Zingiber officinale) powder and paste, J Innov Dev Strateg 7: 60-66.

Ranganna S (1986), Handbook of Analysis and Quality Control for Fruit and Vegetable Products, p 1112
Rao BS and Deshpande V (2006), Experimental Biochemistry, Anshan Ltd.

Sangwan A, Kawatra A and Sehgal S (2014), Nutritional composition of ginger powder prepared using various drying methods, J Food Sci Technol 51: 2260-2262. DOI: org/10.1007/s13197-012-0703-2

Sathe SK, Deshpande SS and Salunkhe DK (1982), Functional properties of winged bean (Psophocarpus tetragonolobus, L) proteins, J. FoodSci. 47: 503-506.

Singh H, Bawa AS and Ahmed J (1997), Dehydration Characteristics of Green Leafy, Indian Food Pack 51: 5-13.

Singh S, Singh N, Isono N and Noda T (2010), Relationship of granule size distribution and amylopectin structure with pasting, thermal and retrogradation properties in wheat starches, J.Agric. Food Chem. 58: 1180-1188

Sosulski FW (1962), The centrifuge method for determining flour absorption in hard red spring wheat, Cereal Chem 39: 344-350. 

